\title{
Effect of temperature, water-phase salt and phenolic contents on Listeria monocytogenes growth rates on cold-smoked salmon and evaluation of secondary models
}

\author{
M. Cornu ${ }^{1, *}$, A. Beaufort ${ }^{1}$, S. Rudelle ${ }^{1}$, L. Laloux ${ }^{1}$, H. Bergis ${ }^{1}$, \\ N. Miconnet ${ }^{1}$, T. Serot ${ }^{2}$, M.L. Delignette-Muller ${ }^{3}$
}

\footnotetext{
${ }^{1}$ Afssa (French food safety agency), 23 avenue du Général de Gaulle, BP19, F-94706 Maisons Alfort cedex, France.

2 Ifremer (French research institute for exploitation of the sea), rue de l'lle d'Yeu, BP 21105, F-44311 Nantes cedex 3, France.

${ }^{3}$ ENVL (Veterinary school of Lyon), 1 avenue Bourgelat, F-69280 Marcy l'Etoile, France.
}

*: Corresponding author : M. Cornu, email address : $\underline{\text { m.simon-cornu@afssa.fr }}$

\begin{abstract}
:
Salting and smoking are ancient processes for fish preservation. The effects of salt and phenolic smoke compounds on the growth rate of L. monocytogenes in cold-smoked salmon were investigated, through physico-chemical analyses, challenge tests on surface of cold-smoked salmon at $4{ }^{\circ} \mathrm{C}$ and $8^{\circ} \mathrm{C}$, and a survey of the literature. Estimated growth rates were compared to predictions of existing secondary models, taking into account the effects of temperature, water phase salt content, phenolic content, and additional factors (e.g. pH, lactate, dissolved CO2). The secondary model proposed by Devlieghere et al. [Food Microbiol. 18 (2001) 53] and modified by Giménez and Dalgaard [J. Appl. Microbiol. 96 (2004) 96] appears appropriate. However, further research is needed to understand all effects affecting growth of L. monocytogenes in cold-smoked salmon and to obtain fully validated predictive models for use in quantitative risk assessment.
\end{abstract}

Keywords: Fishery products. L. monocytogenes. Predictive microbiology. Microbial exposure assessment. Validation criteria. Phenolic compounds. 


\section{Introduction}

Numerous recent or in-process risk assessments have concerned Listeria monocytogenes in sliced and vacuum packed cold-smoked salmon (Buchanan, 1997; Lindqvist and Westöö, 2000; FSANZ, 2002; Beaufort et al., 2002; FDA, 2003; FAO/WHO, 2004). This abundance is clearly justified by the sanitary and economic importance of this issue, but it may also be explained by the relatively good availability of data. L. monocytogenes is indeed a well known foodborne pathogen which has been extensively studied since the first major recognised outbreak in the early 1980s (Schlech et al., 1983). Presence and potential growth of this pathogen in cold-smoked salmon has been widely reviewed (Ben Embarek, 1994; Rorvik, 2000; Ross et al., 2000). However, as noted in most risk assessment reports, there are still research needs to better characterize the contamination data and to improve and validate the tools of predictive microbiology to predict growth of $L$. monocytogenes in cold-smoked salmon.

Predictive microbiology aims to predict microbial behaviour in food over time as a function of different influencing parameters. For a review of such models, see McKellar and Lu (2004). Briefly, primary models describe the evolution of a population of micro-organisms over time under certain conditions whereas secondary models describe how the primary model parameters, e.g. the lag time (lag) and the growth rate $\left(\mu_{\max }\right)$, vary with environmental conditions. They are typically based on data generated in liquid laboratory culture media, whereas they aim to predict growth in food products. Validation is then an important issue. Model validation can be defined as demonstrating the accuracy of the model for a specified use. Ross (1996) and Baranyi et al. (1999) proposed criteria to measure the performance of a model, i.e. their reliability when compared to independent "real-world" data, obtained in inoculated food products (challenge tests) or even in naturally-contaminated products (storage trials), and not used to generate the model.

Dalgaard and Jorgensen (1998) provided an extensive comparison of existing secondary models for L. monocytogenes, on the basis of 100 literature challenge tests in different seafood products (including 26 in cold-smoked salmon) and 13 storage trials in cold-smoked salmon. As stated by the authors, one of the limitations was that the inhibiting effect of smoke components was not taken into account, both because no adequate secondary model was available at that time and because the concentration of smoke components was not measured in products used for challenge tests. The antimicrobial activity of smoke is generally attributed to the phenolic fraction, even if no relationship between concentration of phenolic compounds and growth inhibition has clearly been established (Thurette et al., 1998; Niedziela et al., 1998; Suñen et al., 2001, 2003; Lebois et al., 2004). Since this study, Augustin and Carlier $(2000 a, b)$ have proposed two secondary models taking into account the phenolic content, and Giménez and Dalgaard (2004) have modified two other secondary models to include this phenolic effect.

The objective of the present study was (i) to further investigate the physicochemical characteristics of cold-smoked salmon, including the phenolic content, on the basis of a specific survey, and of former similar studies (Leroi et al., 2001; Espe et al., 2004), and (ii) to characterize how they affect growth of Listeria monocytogenes, on the basis of specific challenge tests and of literature data (Peterson, et al., 1993; Pelroy, et al., 1994; Rosso et al., 1996; Niedziela, et al. 1998; Giménez and Dalgaard, 2004; Lakshmanan and Dalgaard, 2004). The four recently proposed secondary models taking into account the concentration of phenolic compounds (Augustin and Carlier, 2000a, b; Giménez and Dalgaard, 2004), and 7 additional secondary models, were compared and evaluated.

\section{Materials and methods}

\subsection{Physicochemical analyses of French commercial products}

Eight French companies each provided five randomly sampled commercial products, which were received frozen and vacuum-packaged. Water, salt and phenolic contents and $\mathrm{pH}$ were measured, according to procedures described by Leroi et al. $(2000,2001)$. Salt contents (in g/100g) were divided by water contents to obtain water phase salt (WPS) in $\mathrm{g} / 100 \mathrm{ml}$.

Similar results published by Leroi et al. (2001) and Espe et al. (2004) are also presented. Statistical $t$ tests were performed to compare the new results with the previous ones of Leroi et al. (2001), with $=0.05$. 


\subsection{Challenge tests (L. monocytogenes) in $\mathbf{5}$ specific products}

Five French companies were asked to produce a specific batch of cold-smoked salmon, achieving realistic physicochemical goals (high, medium or low levels of smoking and salting). The five batches were denoted $A$ to $E$. Three batches $(A, B, C)$ had been manually dry-salted, one batch $(E)$ had been mechanically dry-salted, whereas batch $D$ underwent both a mechanic dry salting and injection. Only salt was added to the raw fish (i.e. no nitrites, no sugar). They all had been cold-smoked (A: $22-24^{\circ} \mathrm{C}$, B: $23^{\circ} \mathrm{C}$, C: not communicated, D: $25-27^{\circ} \mathrm{C}, \mathrm{E}: 24-26^{\circ} \mathrm{C}$ ) in kilns, using either beech wood (batches $\mathrm{A}$, $B, D, E$ ), or a mixture of woods, including mostly beech and oak (batch $C$ ). Batches $A$ and $C$ were produced in artisanal plants, whereas batches B, D, and E were produced in industrial plants. Samples were received from the plants frozen and vacuum-packaged.

For each batch, two 20-slice sub-batches were thawed overnight at $2^{\circ} \mathrm{C}$ and an $89 \mathrm{~mm}$-diameter disk was excised from each fish slice. Weights of the disks ranged from $15 \mathrm{~g}$ to $20 \mathrm{~g}$. The disks of one subbatch were further inoculated with $L$. monocytogenes and used for a challenge test at $4^{\circ} \mathrm{C}$, while noninoculated off-cuts of the same sub-batch were used for a storage trial at $4^{\circ} \mathrm{C}$, whereas the disks and off-cuts of the other sub-batch were used for a challenge test and a storage trial at $8^{\circ} \mathrm{C}$. Last, all remaining off-cuts of one batch were pooled and the pool was analysed for $\mathrm{pH}$, salt content, and phenolic compounds according to the procedures detailed above. This pooling was chosen to reach some confidence in estimating the average physicochemical characteristics of each batch, but did not enable us to observe any within-batch physicochemical variability (neither between the sub-batches, nor within a sub-batch).

Strain TQA 061, isolated in the laboratory from commercial cold-smoked salmon, and stored at $-24^{\circ} \mathrm{C}$ in a glycerol-containing medium, was used for inoculation of the disks. Prior to challenge testing, the content of one cryotube was thawed, and it was 1/100 diluted in tryptone soya broth (AES, Combourg, France) and cultured 4 days at $10^{\circ} \mathrm{C}$. This first preculture in early stationary phase was $1 / 100$ diluted in tryptone soya broth and cultured 3 days at $10^{\circ} \mathrm{C}$. This second preculture in early stationary phase was $1 / 1000$ diluted in tryptone salt (AES), to obtain the inoculum suspension, at a level of $2.10^{6} \mathrm{cfu}$ per millilitre. A 0.1-ml volume of this inoculation suspension was spread onto each disk, which was then folded, so that the inoculum was sandwiched between the two layers. The folded disks were vacuum-packaged, using a chamber machine Multivac A300/16 (Multivac, Lagny-sur-Marne, France), in polyamide/polyethylene (PA/PE) $30 \mu \mathrm{m} / 70 \mu \mathrm{m}$ film (Euralpack, Saint Pierre du Perray, France), with low transmission rates: 30 to $40 \mathrm{~cm}^{3} \cdot \mathrm{m}^{-2} \cdot$ day $^{-1} \cdot$ bar $^{-1}$ for $\mathrm{O}_{2}\left(23^{\circ} \mathrm{C}, 75 \%\right.$ relative humidity), $90 \mathrm{~cm}^{3} \cdot \mathrm{m}^{-}$ ${ }^{2}$. day ${ }^{-1}$. bar ${ }^{-1}$ for $\mathrm{CO}_{2}\left(23^{\circ} \mathrm{C}, 75 \%\right.$ relative humidity $), 2.5$ g.m ${ }^{-2}$.day ${ }^{-1}$ for $\mathrm{H}_{2} \mathrm{O}\left(23^{\circ} \mathrm{C}, 85 \%\right.$ relative humidity). For each batch, twenty inoculated $89-\mathrm{mm}$ disks were stored at $4^{\circ} \mathrm{C} \pm 1^{\circ} \mathrm{C}$, whereas the twenty other disks were stored at $8^{\circ} \mathrm{C} \pm 1^{\circ} \mathrm{C}$, with continuous temperature monitoring. After various intervals up to 55 days, packages were $1 / 10$ diluted in tryptone salt, and homogenized with a stomacher. L. monocytogenes was enumerated by plating onto Palcam agar (AES) appropriate dilutions of the disks in tryptone salt. Plates were incubated $48 \mathrm{~h} \pm 2 \mathrm{~h}$ at $37^{\circ} \mathrm{C} \pm 1^{\circ} \mathrm{C}$. Cell counts were calculated per square centimetre of salmon surface, so that population densities of $L$. monocytogenes were expressed as log cfu/cm². The theoretical initial contamination, calculated from the contamination level for the inoculation suspension, is $3.5 \log \mathrm{cfu} / \mathrm{cm}^{2}$, which is approximately equivalent to $4 \log \mathrm{cfu} / \mathrm{g}$.

\subsection{Storage trials (naturally occurring food flora) in the same 5 products}

To study the growth of the mesophilic food flora, storage trials of each batch were performed. From the non-inoculated crushed off-cuts of each batch, 36 10g-packs were weighted, and vacuumpackaged (as described above). Then $1810 \mathrm{~g}$-packs were stored up to 55 days at $4^{\circ} \mathrm{C}$, and $1810 \mathrm{~g}$ packs were stored up to 25 days at $8^{\circ} \mathrm{C}$. After various intervals, packs were $1 / 10$ diluted in tryptone salt, and homogenized with a stomacher. The mesophilic food flora was enumerated by plating onto Plate Count Agar (AES) appropriate dilutions of the packs in tryptone salt. Plates were incubated 3 days at $30^{\circ} \mathrm{C}$. Cell counts were expressed as log cfu/g.

\subsection{Estimation of growth rates}

Each L. monocytogenes growth curve was fitted by the model of Baranyi and Roberts (1994) and by the embedded model without lag-phase, using least-squares non linear regression. An F-test was performed to compare both models, with $=0.05$. In all cases but one (Batch $\mathrm{E}, 8^{\circ} \mathrm{C}$ ), the lag time was not significant and the model without lag phase was then selected. This is easily explained by the history of the strain, as the preculture temperature was $10^{\circ} \mathrm{C}$. The parameters of the chosen model 
were also estimated using robust non linear regression, as detailed in Miconnet et al. (in press). All calculations were performed with the software Matlab 6.5 (MathWorks).

When it was appropriate, the same estimation was performed for the food flora, obtained through storage trials.

To validate the secondary models, additional growth rates of $L$. monocytogenes were obtained from published challenge tests. Only products in which the phenolic content was either null or measured were selected. Growth rates in cold-smoked salmon estimated by Giménez and Dalgaard (2004) and Lakshmanan and Dalgaard (2004) were used as published by the authors. Published graphs in smoked salmon (Rosso et al., 1996), and in cold-process (not smoked) salmon (Peterson, et al., 1993; Pelroy, et al., 1994; Niedziela, et al. 1998) were scanned and individual points digitalised. Growth rates were estimated using the same procedure as previously described.

\subsection{Prediction of L. monocytogenes growth rates using secondary models}

Four secondary models, taking into account at least the effects of temperature, water activity (calculated from the $\mathrm{NaCl}$ content) and phenolic content, were used for predictions:

- Model 1, a cardinal model developed by Augustin and Carlier (2000a) on the basis of 1437 literature growth rates, both in broth and in challenge tests;

- Model 2, a cardinal model including interactions between factors (Augustin and Carlier, 2000b), based on the same data set;

- Model 3, a square-root model, developed by Tom Ross, used by FAO/WHO (2004), and modified by Giménez and Dalgaard (2004) to take into account the phenolic effect;

- Model 4, a square-root model, developed by Devlieghere et al. (2001) and similarly modified by Giménez and Dalgaard (2004).

Additional models, not taking into account the phenolic content, were also considered to calculated the validation criteria:

- Models 1', 2', 3' and 4', similar to models 1, 2, 3, and 4, without the phenolic effect,

- Model 5, a polynomial model, based on growth curves in broth, used in Pathogen Modelling Program, a software developed by USDA (2001),

- Model 6, a polynomial model, based on growth curves in broth, used in Growth Predictor, a software developed by IFR (2004),

- Model 7, a square-root model, developed by FDA (2003) on the basis of 29 literature growth curves in smoked fishery products, not taking into account the physicochemical factors.

Models were applied as originally defined by their authors. The water activity, $a_{w}$, was calculated from WPS by the equation used by Augustin and Carlier (personal communication) and Giménez and Dalgaard (2004):

$\mathrm{a}_{\mathrm{w}}=1-0.0052471$ WPS -0.00012206 WPS $^{2}$

When needed in the model and not measured, the water-phase lactate (WPL) level of cold-smoked salmon was assumed to be $90 \mathrm{mM}$ (Tienungoon et al., 2000), which is equivalent to a concentration of sodium lactate $(\mathrm{NaL})$ at $1 \%$. All other concentrations of inhibiting compounds (including dissolved $\mathrm{CO}_{2}$ ) were assumed to be null. As Model 7 provides a distribution of predicted growth rates at each temperature, the average of the distribution was chosen for validation.

\subsection{Validation criteria}

Two criteria, proposed by Ross (1996), were used to compare these models:

- the accuracy factor, which expresses the accuracy of the model predictions ( 1 if all predictions are equal to the observations),

- the bias factor, which expresses the overall bias ( $>1$ for a fail-safe model, $<1$ for a faildangerous model, 1 for an unbiased model).

The null growth rates predicted by models 1 and 2 were by convention replaced by 0.01 day $^{-1}$, to 
obtain numerical values of the validation criteria.

\section{Results and discussion}

\subsection{Physicochemical characteristics}

Forty French commercial products were surveyed and analysed for $\mathrm{pH}$, salt contents, water contents, water-phase salt contents, and phenolic contents (see table 1). Results were compared with those of Leroi et al. (2001), on 13 French commercial products, supposed to be representative of the French traditional production and Espe et al. (2004), on 48 French commercial products, produced by four commercial smoking-houses. Water and salt contents were very similar with those observed by Leroi et al. (2001). Significant differences were observed between both studies regarding two factors: $\mathrm{pH}$ and phenolic contents. Indeed, Leroi et al. (2001) measured "initial" pH in early shelf life, whereas pHvalues were measured later in the shelf life in the present study, which may explain the slightly lower results. Last, Leroi et al. (2001) observed lower phenolic contents, as low as $0.27 \mathrm{mg} / 100 \mathrm{~g}$, and none above $1.1 \mathrm{mg} / 100 \mathrm{~g}$. This difference may be explained by an unexpected sampling or experimental bias or could reflect a recent evolution of the French market. Statistical comparisons could not be performed using results of Espe et al. (2004), as raw results had not been published, but results appeared close to the ones of the present survey.

The measured physicochemical characteristics of the 5 specific products used for challenge tests (see Table 1) were all within the ranges of those of the commercial products (at least from one of the three surveys, see Table 1). However, one batch (C) appeared relatively lightly salted. The phenolic contents of two batches ( $B$ and $E$ ) were relatively low, whereas batch A had a relatively high phenolic content $(2 \mathrm{mg} / 100 \mathrm{~g})$. Last, the initial $\mathrm{pH}$ values were similar to those of Leroi et al. (2001).

\subsection{Growth of L. monocytogenes in specific products}

For each batch $A$ to $\mathrm{E}$, two challenge tests were performed: one at $4^{\circ} \mathrm{C}$, and the other one at $8^{\circ} \mathrm{C}$. Figure 1 presents the ten observed growth curves of L. monocytogenes. It has to be underlined that such growth curves were obtained under particular laboratory conditions (specific products, high inoculum levels, preculture in culture broth...) and do not aim to simulate realistic natural contamination. Indeed, storage trials, monitoring of naturally contaminated products, are the only experiments that really enable us to fully describe this state of natural contamination. Concerning specifically the growth rate $\left(\mu_{\max }\right)$, it is usually accepted that challenge tests, whatever the inoculum level, are an adequate and useful approximation of storage trials, whereas it is far more discussed for the two other parameters of primary growth models, the lag time (lag) and the maximum population density (MPD or $N_{\max }$ ). For a further discussion of this, see Gnanou-Besse et al. (submitted).

These extreme physico-chemical conditions of batches $A$ to $E$ were intentionally selected to better characterize the effects of salting and smoking on the growth rate of $L$. monocytogenes at two temperatures. In one combination (batch $A, 4^{\circ} \mathrm{C}$ ), less than three generations of L. monocytogenes were observed within 55 days. At $8^{\circ} \mathrm{C}$, this highly smoked batch was associated to the slowest growth. These results confirm that the impact of phenolic compounds at a very high level, $2 \mathrm{mg} / 100 \mathrm{~g}$, superior to the levels usually encountered on the market.

These growth curves were modelled by a primary model, using the classical least-squares criterion or an alternative robust criterion. Results of the two methods were close (Table 2) and those of the classical least-squares regression were used for further discussion.

The similarity of growth rates at $4^{\circ} \mathrm{C}$ and $8^{\circ} \mathrm{C}$ of batch $\mathrm{B}$ was unexpected. This unexpected result might be (at least partly) due to estimation uncertainty. Note that the obtained growth curves, both at $4^{\circ} \mathrm{C}$ and $8^{\circ} \mathrm{C}$, are far from ideal exponential growth curves. The uncertainty on the estimation of growth rates is then high. As discussed in Miconnet et al. (in press), surface growth curves are often less satisfactory than crushed growth curves, due to an heterogeneity between packs, which are not homogenised in the 1st case, whereas they are in the latter case.

This unexpected result of batch B could also be explained by the within-batch variability. Indeed, there could have been a difference between the sub-batch used for the growth curve at $4^{\circ} \mathrm{C}$ and the subbatch used for the growth curve at $8^{\circ} \mathrm{C}$.

Moreover, at $4^{\circ} \mathrm{C}$, the growth rate in batch $\mathrm{B}$ is higher than in batch $\mathrm{E}$, and the opposite is observed at $8^{\circ} \mathrm{C}$, whereas batches $\mathrm{B}$ and $\mathrm{E}$ have similar physicochemical characteristics. This may be explained 
by the estimation uncertainty discussed above. It also illustrates the fact that the measured physicochemical characteristics probably do not account for all the between-batches and within-batch variability.

\subsection{Growth of the food flora in specific products}

Figure 2 presents the growth curves of the mesophilic food flora in storage trials at $4^{\circ} \mathrm{C}$ and $8^{\circ} \mathrm{C}$. The two artisanal batches, denoted $A$ and $C$, had relatively high initial plate count numbers. It was then possible to estimate, at least roughly, the growth rates of the mesophilic food flora. This estimation is very approximate as storage trials are less appropriate than challenge tests for such fittings. Moreover the growth rate is usually defined for a single species, whereas it is used in this case for a mixture of species. The least-squares estimations were: 0.27 day $^{-1}$ (batch $\mathrm{A}, 4^{\circ} \mathrm{C}$ ), 0.58 day $^{-1}$ (batch $\mathrm{A}, 8^{\circ} \mathrm{C}$ ), 0.96 day $^{-1}$ (batch $\mathrm{C}, 4^{\circ} \mathrm{C}$ ), and 0.86 day $^{-1}$ (batch $\mathrm{C}, 8^{\circ} \mathrm{C}$ ). The robust estimations were close: 0.27 day $^{-}$ ${ }^{1}$ (batch $\left.\mathrm{A}, 4^{\circ} \mathrm{C}\right), 0.63$ day $^{-1}$ (batch $\mathrm{A}, 8^{\circ} \mathrm{C}$ ), 0.91 day $^{-1}$ (batch $\mathrm{C}, 4^{\circ} \mathrm{C}$ ), and 0.89 day $^{-1}$ (batch $\mathrm{C}, 8^{\circ} \mathrm{C}$ ). The fact that the growth is at both temperatures faster in the lightly salted batch $C$ than in the heavily smoked batch A can easily be explained by the physicochemical difference between the two subbatches. Indeed, most indigenous microbial flora are probably, at least partly, inhibited by salt and phenolic compounds. On the contrary, it was less expected that the microbial growth in batch $\mathrm{C}$ at $4^{\circ} \mathrm{C}$ could be as fast (or even faster) than at $8^{\circ} \mathrm{C}$ in the same batch. This might be partly explained by the hypothesis that some species present in the cold-smoked salmon could have an optimal temperature close to these temperatures (but would also be able to form colonies on PCA at $30^{\circ} \mathrm{C}$ in 3 days).

For these two batches, and especially for batch A, the population levels reached by the food flora in storage trials is close or even higher than the contamination levels of $L$. monocytogenes in challenge tests. Then, it is possible that, in these two batches, the observed growth of L. monocytogenes had been influenced by the simultaneous growth of a non-neglectable or even predominant background flora. It has often been observed that the major interaction observed in cold-smoked salmon between the background flora (among which the lactic acid flora tends to be predominant) and $L$. monocytogenes is a competition, the so-called Jameson effect, with a simultaneous deceleration of all populations (see Buchanan et al., 1997, 1999; Dalgaard and Jorgensen, 1998; Ross et al., 2000; Cornu, 2001; FAO/WHO, 2004; Giménez and Dalgaard, 2004; Nilsson et al., 2005). Even if the data are not appropriate to detect such an effect, the deceleration of $L$. monocytogenes at a relatively low level (ca. $10^{6} \mathrm{cfu} / \mathrm{cm}^{2}$ ), in batch $A$ at $8^{\circ} \mathrm{C}$, after ca. 20 days, could be explained by the simultaneous deceleration of the food flora (observed in storage trials after ca. 17 days at $8^{\circ} \mathrm{C}$ ).

This Jameson effect only impacts the maximum population density of L. monocytogenes and not its growth rate, which was the major focus of this paper. Then, we assume that the estimations of the growth rates in these batches were not influenced by the background flora. On the contrary, the observed maximal population densities observed by L. monocytogenes may be lower than those obtained in absence of this predominant background flora.

For the three industrial batches, denoted B, D, and E, the initial population was so low, that most packs could not be enumerated using standard techniques (with a quantification threshold at 10 $\mathrm{cfu} / \mathrm{g}$ ). It is then impossible for these batches to estimate the growth rates. However, in the case of batch $\mathrm{B}$, it cannot be excluded that the growth at $4^{\circ} \mathrm{C}$ could be close to the growth at $8^{\circ} \mathrm{C}$ (as enumeration results are similar at the 18th day). This could confirm that there was a difference between the physicochemical characteristics of the sub-batch used at $4^{\circ} \mathrm{C}$ and the sub-batch used at $8^{\circ} \mathrm{C}$. This could also be explained by species with a low optimal temperature, as for the food flora of batch $C$ discussed above. For these three batches, L. monocytogenes was strongly predominant in the challenge tests and we can then exclude that any competition effect occurred during the experiments. However, as realistic initial contamination levels of $L$. monocytogenes are very low (see Beaufort et al., submitted), competition should be taken into account when predicting the evolution of L. monocytogenes in naturally contaminated products, even for these batches with a relatively initial level in background flora.

\subsection{Comparison and validation of $L$. monocytogenes secondary models}

Published secondary models were evaluated in this study. Predicted growth rates are compared with estimated growth rates of the present study in Table 2. Predictions of models 1 and 2 were much lower than the observations (i.e. fail-dangerous). Predictions of models 3 and 4 were more consistent with estimated growth rates, even if model 3 tended to be fail-dangerous at $4^{\circ} \mathrm{C}$. The estimated growth rate for batch $\mathrm{E}$ at $8^{\circ} \mathrm{C}, 1.63$ day $^{-1}$, appears relatively high when compared with the other estimations and with the predictions. For this specific growth curve, the lag time was significantly non null, but its 
biological significance can be questioned. Indeed, with a null lag time, the estimated growth rate is 0.92 day $^{-1}$, which appears more consistent with the predictions. This example is an indication that the estimation procedure of the growth parameters is much more complex in the case of challenge tests, than in the case of curves in broth.

For the sake of comparison, models 1, 3 and 4 were rewritten into a unified five-parameter equation:

$$
\mu=\mu_{\text {ref }} \cdot \frac{\left(\mathrm{T}-\mathrm{T}_{\min }\right)^{2}}{\left(\mathrm{~T}_{\text {ref }}-\mathrm{T}_{\min }\right)^{2}} \cdot \frac{\left(\mathrm{WPS}-\mathrm{WPS}_{\max }\right)+0.02326\left(\mathrm{WPS}^{2}-\mathrm{WPS}_{\max }{ }^{2}\right)}{\left(\mathrm{WPS}_{\text {ref }}-\mathrm{WPS}_{\max }\right)+0.02326\left(\mathrm{WPS}_{\mathrm{ref}}{ }^{2}-\mathrm{WPS}_{\max }{ }^{2}\right)} \cdot \frac{\left(\mathrm{P}_{\max }-\mathrm{P}\right)^{\mathrm{k}}}{\left(\mathrm{P}_{\max }-\mathrm{P}_{\mathrm{ref}}\right)^{\mathrm{k}}}(2)
$$

where $T_{\min }$ is the minimal temperature, WPS $S_{\max }$ the MIC-value for WPS, calculated from the minimal $a_{w}$ of each model, using Equation (1), $P_{\max }$ the phenolic MIC-value, $\mathrm{k}$ equals 1 or 2 , and $\mu_{\mathrm{ref}}$ the predicted growth rate for a reference cold-smoked salmon at a reference temperature, i.e. the prediction of the model for the following conditions: $T=T_{\text {ref }}=5^{\circ} \mathrm{C} ; \mathrm{pH}=6.20 ; \mathrm{WPS}_{\text {ref }}=5.0 \% ; \mathrm{P}=\mathrm{P}_{\text {ref }}=1.0 \mathrm{mg} / 100 \mathrm{~g}=$ $10 \mathrm{ppm} ; \mathrm{WPL}=8000 \mathrm{ppm}=90 \mathrm{mM}$, corresponding to $\mathrm{NaL}=1 \% ; \mathrm{CO}_{2 \text { diss }}=0 \mathrm{ppm}$.

The reference values for $\mathrm{pH}$, WPS and $\mathrm{P}$, were arbitrarily set at rounded average values (see Table 1 ), whereas the choice of the reference value for lactate concentrations was based on Tienungoon et al. (2000).

Table 3 presents the parameters of Models 1, 3 and 4. Model 2 could not be rewritten in such a unified form, moreover it predicts a null growth rate for the reference cold-smoked salmon at the reference temperature. This presentation was conceived to compare models. Thus, the very low phenolic MICvalue $\left(P_{\max }\right)$ of model 1 is sufficient to explain why model 1 was highly fail-dangerous in smoked products, whereas it was much more appropriate and even slightly fail-safe in non-smoked products, in which the phenolic effect was not modelled. The minimal temperature of model $3,+0.88^{\circ} \mathrm{C}$, appears relatively high, which may explain why this model behaves better at $8^{\circ} \mathrm{C}$ than at $4^{\circ} \mathrm{C}$.

Equation (2) was also designed to enhance simpler use of these models. When no information concerning the salt content is available, the term describing its effect can simply be omitted. The water phase salt content is then assumed to be $5 \%$. Similarly, if the term describing the effect of phenol is omitted, the phenolic content is assumed to be $1 \mathrm{mg} / 100 \mathrm{~g}$.

Table 4 presents the validation criteria based on different sets of growth rates: the 10 challenge tests on cold-smoked salmon of the present study, the 9 challenge tests on/in cold-smoked salmon taken from literature, and the 22 challenge tests in cold-process non-smoked salmon. Eleven secondary models were tested. Among the four models taking into account the phenolic effect, model 4 was the most accurate model (lowest $A f$-value) on each data set. It was slightly biased, in a fail-safe way, $(B f>1)$ but such a bias is usually preferred to a fail-dangerous bias. Model 4 is then a good candidate to take into account the effect of all physicochemical factors, including the phenolic content, on growth rates of $L$. monocytogenes.

However, satisfactory validation criteria were also obtained with some other models, especially with model 7. As this model was directly built from growth rates estimated in challenge tests, $B f$-values close to 1.0 were expected and were indeed obtained. More surprisingly, the Af-values obtained with this approach, in which only the temperature effect was modelled, were close or better than the Afvalues obtained with models taking into account the physicochemical factors, such as model 4.

Thus, the described between-product physicochemical variability does not appear sufficient to fully explain the between-curve variability of growth rates. Our description of the between-product physicochemical variability may be improved. Thus, the effect of organic acids was only taken into account through the initial $\mathrm{pH}$, whereas the production of lactic acid by the background flora could have been specifically considered. The measurement of WPS is probably not sufficient to study the water activity, as sucrose, measured by Espe et al. (2004) in French products, or other solutes may also lower it. The within-batch variability, e.g. the variability of the WPS due to this more or less equal repartition of the salt (which could depend on the salting method), was not considered in this study but could have a great impact, as suggested by some unexpected results. Last, Brocklehurst (2003) reviews numerous studies which demonstrate that the microstructure of the food impacts the microbial growth.

In a broader context, additional preservatives, which are forbidden in France and were not used in the batches selected for these experiments, may be taken into account. For example, when they have been used, nitrites had a significant effect (Pelroy et al., 1994).

Then, additional sources of between-product and within-product variability have still to be investigated, before a full validation of secondary models based on physicochemical characteristics. Investigation of secondary models based on a alternative description of the variability could also be valuable. 


\subsection{Phenolic effect}

The highly fail-dangerous characteristic of models 1 and 2 can be easily explained, as Augustin and Carlier $(2000 a, b)$ based their estimations of the phenolic MIC-value on experimental results in which a phenolic concentration of $1.25 \mathrm{mg} / 100 \mathrm{ml}$ in broth was inhibitory for L. monocytogenes (Membré et al., 1997), whereas a concentration of $2 \mathrm{mg} / 100 \mathrm{~g}$ is not, at least at $8^{\circ} \mathrm{C}$, in our results. This apparent contradiction may be explained by a difference between the behaviour of phenolic compounds in broth versus fish. The solubility of these compounds in the water phase of a fatty fish is rather unknown, but it can be expected to be low and dependent on the nature of smoke and the temperature. Second, the phenolic concentration is probably not sufficient to assess the antimicrobial activity of smoke. Suñen et al. (2001) observed growth of $L$. monocytogenes at $5^{\circ} \mathrm{C}$ in broth at a phenolic concentration as high as $10.75 \mathrm{mg} / 100 \mathrm{ml}$, but no growth at a phenolic concentration of $2.3 \mathrm{mg} / 100 \mathrm{ml}$, with another smoke extract.

Last, the between-strain variability in sensitivity to phenolic compounds should also be considered. According to results of Thurette et al. (1998), a concentration of $1.1 \mathrm{mg} / 100 \mathrm{~g}$ in cold-smoked fish at $4^{\circ} \mathrm{C}$ was inhibitory for their reference strain but not for a cocktail of three strains, including one isolated from smoked fish.

Thus, results appear relatively controversial. The nature of the smoke, either wood smoke or liquid smoke, and the analytical procedure to measure phenolic concentrations differ from one study to another and this may add confusion. Even if the MIC-value chosen by Giménez and Dalgaard (2004) appears satisfactory on the basis of the results presented in this paper, numerous questions raised regarding the solubility of phenolic compounds, the between-strain variability, and the impact of nonphenolic smoke have still to be discussed.

\section{Conclusion}

Physiochemical characteristics of cold-smoked salmon, especially the contents in salt and phenolic compounds, affect growth rates of $L$. monocytogenes. Secondary models can be used to model these effects and, among the four tested models, the secondary model proposed by Devlieghere et al. (2001) and modified by Giménez and Dalgaard (2004) appeared the most appropriate one. However, it was obvious that the studied factors, including the phenolic content, were not sufficient to describe the whole variability of the behaviour of $L$. monocytogenes in cold-smoked salmon. Additional sources of uncertainty and variability affecting the growth rate should be considered, such as the betweenstrain variability and a between-product variability which is not explained by the measured physicochemical factors.

\section{References}

Augustin, J.C., Carlier, V., 2000a. Mathematical modelling of the growth rate and lag time for Listeria monocytogenes. International Journal of Food Microbiology 56, 29-51.

Augustin, J.C., Carlier, V., 2000b. Modelling the growth rate of Listeria monocytogenes with a multiplicative type model including interactions between environmental factors. International Journal of Food Microbiology 56, 53-70

Baranyi, J., Pin, C., Ross, T., 1999. Validating and comparing predictive models. International Journal of Food Microbiology 48, 159-166.

Baranyi, J., Roberts, T.A., 1994. A dynamic approach to predicting bacterial growth in food. International Journal of Food Microbiology 23, 277-294.

Beaufort, A. , Bergis, H., Brisabois, A., Cornu, M., Delignette-Muller, M.L., Gnanou-Besse, N., Laloux, L., Malle, P., Morelli, E., Pouillot, R. , Salvat, G., 2002. On-going project: towards an interdisciplinary description of the factors affecting exposure to $L$. monocytogenes in chilled products. Working Group 3, COST 920, 7-8 march 2002, RIVM, Netherlands. 
Beaufort, A., Rudelle, S., Gnanou-Besse, N., Toquin, M.T., Kerouanton, A, Bergis, H., Salvat, G., Cornu, M., submitted. Prevalence, characterization and growth of Listeria monocytogenes in naturally contaminated cold smoked salmon. International Journal of Food Microbiology.

Ben Embarek, P. K., 1994. Presence, detection and growth of Listeria monocytogenes in seafoods: a review. International Journal of Food Microbiology 23, 17-34.

Brocklehurst, T., 2003. Challenge of food and the environment. In: McKellar, R.C., Lu, X. (Eds.) Modeling microbial responses in food. CRC Series in Contemporary Food Science, CRC Press, pp. 21-62.

Buchanan, R.L., 1997. Use of epidemiologic and food survey data to estimate a purposefully conservative dose-response relationship for Listeria monocytogenes levels and incidence of listeriosis. Journal of Food Protection 60, 918-922.

Buchanan, R.L., Bagi, L.K., 1997. Microbial competition: effect of culture conditions on the suppression of Listeria monocytogenes Scott A by Carnobacterium piscicola. Journal of Food Protection 60, 254-261.

Buchanan, R.L., Bagi, L.K., 1999. Microbial competition: effect of Pseudomonas fluorescens on the growth of Listeria monocytogenes. Food Microbiology 16, 523-529.

Cornu, M., 2001. Modelling the competitive growth of Listeria monocytogenes and food flora in situ. Acta Horticulturae (ISHS) 566, 151-157.

Dalgaard, P., Jorgensen, L.V., 1998. Predicted and observed growth of Listeria monocytogenes in seafood challenge tests and in naturally contaminated cold-smoked salmon. International Journal of Food Microbiology 40, 105-15.

Devlieghere, F., Geeraerd, A.H., Versyck, K. J., Vandewaetere, B., van Impe, J., Debevere, J., 2001. Growth of Listeria monocytogenes in modified atmosphere packed cooked meat products: a predictive model. Food Microbiology 18, 53-66.

Espe, M., Kiessling, A., Lunestad, B.T., Torrissen, O.J., Bencze Rørå, A.M., 2004. Quality of coldsmoked salmon collected in one French hypermarket during a period of 1 year. Lebensmittel Wissenschaft und Technologie 37, 617-638.

FAO/WHO, 2004. Risk Assessment of L. monocytogenes in ready-to-eat foods. Technical report. Microbiological Risk Assessment Series 5. FAO/WHO 2004 (ISBN 92-5-105127-5)

FDA, 2003. Quantitative Assessment of Relative Risk to Public Health from Foodborne Listeria monocytogenes Among Selected Categories of Ready-to-Eat Foods. http://www.foodsafety.gov/ dms/lmr2-toc.html

FSANZ (2002). Final assessment. Report proposal P239. L. monocytogenes risk assessment, risk management strategy. http://www.anzfa.gov.au/standardsdevelopment/proposals

Giménez, B., Dalgaard, P., 2004. Modelling and predicting the simultaneous growth of Listeria monocytogenes and spoilage micro-organisms in cold-smoked salmon. Journal of Applied Microbiology 96, 96-109.

Gnanou Besse, N., Audinet, N., Barre, L., Cauquil, A., Cornu, M., Colin, P., submitted. Effect of the inoculum size on Listeria monocytogenes growth in solid media. International Journal of Food Microbiology.

IFR, 2004. Growth predictor. http://www.ifr.ac.uk/Safety/GrowthPredictor/

Lakshmanan, R., Dalgaard, P., 2004. Effects of high-pressure processing on Listeria monocytogenes, spoilage microflora and multiple compound quality indices in chilled cold-smoked salmon. Journal of Applied Microbiology 96, 398-408. 
Lammerding, A.M., Fazil, A., 2000. Hazard identification and exposure assessment for microbial food safety risk assessment. International Journal of Food Microbiology 58, 147-57.

Lebois, M., Connil, N., Onno, B., Prevost, H., Dousset, X., 2004. Effects of divercin V41 combined to $\mathrm{NaCl}$ content, phenol (liquid smoke) concentration and $\mathrm{pH}$ on Listeria monocytogenes ScottA growth in BHI broth by an experimental design approach. Journal of Applied Microbiology 96, 931-7.

Leroi F., Joffraud J.J., Chevalier F., 2000. Effect of salt and smoke on the microbiological quality of cold-smoked salmon during storage at 5 degrees $\mathrm{C}$ as estimated by the factorial design method. Journal of Food Protection 63, 502-508.

Leroi, F., Joffraud, J. J., Chevalier, F., Cardinal, M., 2001. Research of quality indices for cold-smoked salmon using a stepwise multiple regression of microbiological counts and physico-chemical parameters. Journal of Applied Microbiology 90, 578-87.

Lindqvist R., Westöö A., 2000. Quantitative risk assessment for Listeria monocytogenes in smoked or gravad salmon and rainbow trout in Sweden. International Journal of Food Microbiology 58, 181-96.

McKellar, R.C., Lu, X., 2003. Modeling microbial responses in food, 343 pp. CRC Series in Cotemporary Food Science, CRC Press, (ISBN 084931237X).

Membré J.M., Thurette J., Catteau M., 1997. Modelling the growth, survival and death of Listeria monocytogenes. Journal of Applied Microbiology 82, 345-350.

Miconnet, C., Geeraerd, A. H., Van Impe, J. F., Rosso, L., Cornu, M., in press. Reflections on the application of primary models to describe challenge tests conducted in/on food products. International Journal of Food Microbiology.

Niedziela, J. C., MacRae, M., Ogden, I. D., Nesvadba, P., 1998. Control of Listeria monocytogenes in salmon: antimicrobial effect of salting, smoking and specific smoke compounds. Lebensmittel Wissenschaft und Technologie 31, 155-161.

Nilsson, L., Hansen, T.B., Garrido, P., Buchrieser, C., Glaser, P., Knochel, S., Gram, L., Gravesen, A., 2005. Growth inhibition of Listeria monocytogenes by a nonbacteriocinogenic Carnobacterium piscicola. Journal of Applied Microbiology 98, 172-83.

Pelroy, G., Peterson, M., Rohinee, P., Almond, J., Eklund, M., 1994. Inhibition of Listeria monocytogenes in cold-process (smoked) salmon by sodium nitrite and packaging method. Journal of Food Protection 57, 114-119.

Peterson, M. E., Pelroy, G. A., Paranjpye, R. N., Poysky, F. T., Almond, J. S., Eklund, M. W., 1993. Parameters for control of Listeria monocytogenes in smoked fishery products: sodium chloride and packaging method. Journal of Food Protection 56, 938-943.

Rorvik L. M., 2000. Listeria monocytogenes in the smoked salmon industry. International Journal of Food Microbiology 62, 183-90.

Ross T., Dalgaard P., Tienungoon S., 2000. Predictive modelling of the growth and survival of Listeria in fishery products. International Journal of Food Microbiology 62 (3), 231-245.

Ross T., 1996. Indices for performance evaluation of predictive models in food microbiology. Journal of Applied Microbiology 81, 501-508.

Rosso, L., Bajard, S., Flandrois, J.P., Lahellec, C., Fournaud, J., Veit, P., 1996. Differential growth of Listeria monocytogenes at 4 and $8^{\circ} \mathrm{C}$ : consequences for the shelf life of chilled products. Journal of Food Protection 59, 944-949.

Schlech, W.F., Lavigne, P.M., Bortolussi, R.A., Allen, A.C., Haldane, E.V., Wort, A.J., Hightower, A.W., Johnson, S.E., King, S.H., Nicholls, E.S., Broome, C.V., 1983. Epidemic listeriosis evidence for transmission by food. New England Journal of Medicine 308, 203-206. 
Suñen E., Fernandez-Galian B., Aristimuno C., 2001. Antibacterial activity of smoke wood condensates against Aeromonas hydrophila, Yersinia enterocolitica, and Listeria monocytogenes at low temperature. Food Microbiology 18, 387-393.

Suñen, E., Aristimuno, C., Fernandez-Galian, B., 2003. Activity of smoke wood condensates against Aeromonas hydrophila, and Listeria monocytogenes in vacuum-packaged, cold-smoked rainbow trout stored at $4^{\circ} \mathrm{C}$. Food Research International 36, 111-116.

Thurette J., Membré J.M., Han Ching L., Tailliez R., Catteau M., 1998. Behavior of Listeria spp. in smoked fish products affected by liquid smoke, $\mathrm{NaCl}$ concentration, and temperature. Journal of Food Protection 61, 1475-1479.

Tienungoon, S., Ratkowsky, D. A., McMeekin, T. A., Ross, T., 2000. Growth limits of Listeria monocytogenes as a function of temperature, $\mathrm{pH}, \mathrm{NaCl}$, and lactic acid. Applied Environmental Microbiology 66, 4979-87.

USDA, 2001. Pathogen Modeling Program. http://www.arserrc.gov/mfs/PATHOGEN.HTM 
Table 1.

\begin{tabular}{lllll}
\hline $\mathrm{pH}$ & $\begin{array}{l}\text { Salt content } \\
(\mathrm{g} / 100 \mathrm{~g})\end{array}$ & $\begin{array}{l}\text { WPS } \\
(\mathrm{g} / 100 \mathrm{ml})\end{array}$ & $\begin{array}{l}\text { Water } \\
\text { content }\end{array}$ & $\begin{array}{l}\mathrm{P}=\text { phenolic } \\
\text { content } \\
(\mathrm{mg} / 100 \mathrm{~g})\end{array}$
\end{tabular}

\begin{tabular}{|c|c|c|c|c|c|}
\hline \multicolumn{6}{|c|}{40 commercial French products (present survey): } \\
\hline Mean (SD) & $6.02(0.09)$ & $2.85(0.65)$ & $4.62(0.96)$ & $61.3(3.57)$ & $0.99(0.30)$ \\
\hline [Min-Max] & [5.80-6.24] & [1.60-4.10] & [2.74-7.12] & [53.1-68.7] & [0.55-1.65] \\
\hline \multicolumn{6}{|c|}{13 commercial French products (Leroi et al., 2001): } \\
\hline Mean (SD) & $6.20(0.07)$ & $3.13(0.56)$ & $5.18(0.90)$ & $60.5(3.08)$ & $0.55(0.26)$ \\
\hline [Min-Max] & [6.09-6.30] & [2.21-4.29] & [3.76-7.19] & [57.3-68.0] & [0.27-1.08] \\
\hline \multicolumn{6}{|c|}{48 commercial French products (Espe et al., 2001): } \\
\hline Mean (SD) & n.d. & $2.62(\mathrm{nd})$ & n.d. & $62.5(\mathrm{nd})$ & $0.88(\mathrm{nd})$ \\
\hline [Min-Max] & & {$[1.3-3.4]$} & & {$[57.7-66.7]$} & {$[0.3-2.1]$} \\
\hline \multicolumn{6}{|c|}{5 specific batches, used for challenge tests: } \\
\hline A & 6.20 & 2.70 & 4.82 & 56.3 & 2.00 \\
\hline$B$ & 6.20 & 3.90 & 6.20 & 62.9 & 0.51 \\
\hline C & 6.20 & 1.40 & 2.31 & 60.9 & 0.97 \\
\hline D & 6.20 & 3.70 & 6.82 & 54.4 & 1.45 \\
\hline$E$ & 6.10 & 3.20 & 5.73 & 56.1 & 0.51 \\
\hline
\end{tabular}

Table 1: Physicochemical characteristics $(\mathrm{pH}$, salt content, water-phase salt content calculated from salt and water contents, and phenolic content) of cold-smoked salmon. For the present survey (40 French commercial products) and the survey of Leroi et al. (2001), mean, standard deviation, and extreme values are shown. Individual results are presented for the five specific batches (labelled A to E) used for challenge tests. 
Table 2.

\begin{tabular}{|c|c|c|c|c|c|c|}
\hline \multirow{2}{*}{$\begin{array}{l}\text { Conditions } \\
\text { Batch, Temp. }\end{array}$} & \multicolumn{2}{|c|}{ Estimated growth rates $\left(\right.$ day $\left.^{-1}\right)$} & \multicolumn{4}{|c|}{ Predicted growth rates $\left(\right.$ day $\left.^{-1}\right)$} \\
\hline & Least-squares & Robust & Model 1 & Model 2 & Model 3 & Model 4 \\
\hline $\mathrm{A}, 4^{\circ} \mathrm{C}$ & 0.02 & 0.01 & 0 & 0 & 0.06 & 0.13 \\
\hline $\mathrm{B}, 4^{\circ} \mathrm{C}$ & 0.50 & 0.48 & 0.12 & 0 & 0.14 & 0.29 \\
\hline $\mathrm{C}, 4^{\circ} \mathrm{C}$ & 0.31 & 0.35 & 0.04 & 0 & 0.18 & 0.40 \\
\hline $\mathrm{D}, 4^{\circ} \mathrm{C}$ & 0.29 & 0.31 & 0 & 0 & 0.07 & 0.15 \\
\hline $\mathrm{E}, 4^{\circ} \mathrm{C}$ & 0.27 & 0.27 & 0.13 & 0 & 0.14 & 0.32 \\
\hline $\mathrm{A}, 8^{\circ} \mathrm{C}$ & 0.27 & 0.30 & 0 & 0 & 0.31 & 0.30 \\
\hline $\mathrm{B}, 8^{\circ} \mathrm{C}$ & 0.49 & 0.49 & 0.29 & $<0.01$ & 0.72 & 0.67 \\
\hline $\mathrm{C}, 8^{\circ} \mathrm{C}$ & 1.00 & 1.04 & 0.09 & $<0.01$ & 0.93 & 0.94 \\
\hline $\mathrm{D}, 8^{\circ} \mathrm{C}$ & 0.80 & 0.79 & 0 & 0 & 0.38 & 0.35 \\
\hline $\mathrm{E}, 8^{\circ} \mathrm{C}$ & $1.63^{\mathrm{a}}$ & 1.63 & 0.32 & $<0.01$ & 0.74 & 0.74 \\
\hline
\end{tabular}

a: the estimation of 1.63 day $^{-1}$ for batch $E$ at $8^{\circ} \mathrm{C}$ is obtained with the 4-parameter Baranyi model. With a null lag time, the estimated growth rate is 0.92 day $^{-1}$.

Table 2: Estimated and predicted growth rates $\left(\right.$ day $\left.^{-1}\right)$ of $L$. monocytogenes on cold-smoked salmon at $4^{\circ} \mathrm{C}$ and $8^{\circ} \mathrm{C}$. Estimations were obtained fitting each growth curve using the chosen model (see Figure 1) and non-linear least-squares and robust regression (Miconnet et al., in press). Predictions were obtained using four secondary models, and the physico-chemical characteristics of each product (see Table 1). Model 1: Augustin and Carlier (2000a). Model 2: Augustin and Carlier (2000b). Model 3: Ross (FAO/WHO, 2004), modified by Giménez and Dalgaard (2004). Model 4: Devlieghere et al (2001), modified by Giménez and Dalgaard (2004).

Table 3.

\begin{tabular}{lccc} 
Parameters & Model 1 & Model 3 & Model 4 \\
\hline$\mu_{\text {ref }}\left(\right.$ day $\left.^{-1}\right)$ & 0.03 & 0.23 & 0.43 \\
$\mathrm{~T}_{\min }\left({ }^{\circ} \mathrm{C}\right)$ & -2.7 & 0.9 & -3.5 \\
$\mathrm{WPS}_{\min }(\mathrm{g} / 100 \mathrm{~mL})$ & 13.1 & 11.6 & 10.7 \\
$\mathrm{P}_{\max }(\mathrm{mg} / 100 \mathrm{~g})$ & 1.25 & 2.81 & 2.81 \\
$\mathrm{k}$ & 2 & 1 & 1 \\
\hline
\end{tabular}

Table 3. Parameters of three models in a unified and simplified equation (see Equation (2) in the text). Model 1: Augustin and Carlier (2000a). Model 3: Ross (FAO/WHO, 2004), modified by Giménez and Dalgaard (2004). Model 4: Devlieghere et al (2001), modified by Giménez and Dalgaard (2004). 
Table 4.

\begin{tabular}{|c|c|c|c|c|c|c|c|c|c|c|c|}
\hline & $\begin{array}{c}\text { Model } \\
1^{\mathrm{a}}\end{array}$ & $\begin{array}{l}\text { Model } \\
2^{\mathrm{a}}\end{array}$ & $\begin{array}{c}\text { Model } \\
3\end{array}$ & $\begin{array}{c}\text { Model } \\
4\end{array}$ & $\begin{array}{c}\text { Model } \\
1^{\prime}\end{array}$ & $\begin{array}{c}\text { Model } \\
2^{\prime}\end{array}$ & $\begin{array}{c}\text { Model } \\
3^{\prime}\end{array}$ & $\begin{array}{c}\text { Model } \\
4^{\prime}\end{array}$ & $\begin{array}{c}\text { Model } \\
5\end{array}$ & $\begin{array}{c}\text { Model } \\
6\end{array}$ & $\begin{array}{c}\text { Model } \\
7\end{array}$ \\
\hline \multicolumn{12}{|c|}{10 growth rates of the present study } \\
\hline$A_{f}$ & 7.5 & $>10$ & 1.9 & 1.7 & 4.2 & $>10$ & 2.0 & 2.0 & 3.1 & 2.3 & 1.8 \\
\hline$B_{f}$ & 0.1 & $<0.1$ & 0.7 & 1.1 & 0.4 & 0.1 & 1.3 & 1.9 & 3.1 & 2.2 & 1.3 \\
\hline \multicolumn{12}{|c|}{9 growth rates in cold-smoked salmon (literature) } \\
\hline$A_{f}$ & $>10$ & $>10$ & 1.7 & 1.6 & 2.9 & 8.4 & 2.2 & 2.8 & 3.9 & 2.7 & 1.8 \\
\hline$B_{f}$ & $<0.1$ & 0.1 & 1.1 & 1.6 & 2.9 & 0.1 & 2.1 & 2.8 & 3.9 & 2.7 & 1.8 \\
\hline \multicolumn{12}{|c|}{$10+9=19$ growth rates in cold-salmon products (all sources) } \\
\hline$A_{f}$ & $>10$ & $>10$ & 1.8 & 1.6 & 3.5 & $>10$ & 2.1 & 2.4 & 3.4 & 2.5 & 1.8 \\
\hline$B_{f}$ & 0.1 & $<0.1$ & 0.9 & 1.3 & 1.0 & 0.1 & 1.6 & 2.3 & 3.4 & 2.5 & 1.5 \\
\hline \multicolumn{12}{|c|}{22 growth rates in salted (non-smoked) salmon (literature) } \\
\hline$A_{f}$ & 1.7 & 5.2 & 1.6 & 1.5 & 1.7 & 5.2 & 1.6 & 1.5 & 2.3 & 1.5 & 1.5 \\
\hline$B_{f}$ & 1.6 & 0.2 & 1.0 & 1.5 & 1.6 & 0.2 & 1.0 & 1.5 & 2.3 & 1.5 & 0.8 \\
\hline
\end{tabular}

a : For models 1 and 2, the criteria are not defined, as some predicted growth rates are equal to 0 . To obtain numerical values, null predictions were replaced by 0.01 day $^{-1}$

Table 4. Validation criteria of models 1 to 4 based on 41 growth rates of L. monocytogenes: 10 challenge tests on cold-smoked salmon in the present study (see Figure 1 and Table 2, the leastsquares criterion and the model without any lag phase was selected for all curves), 9 challenge tests on/in cold-smoked salmon taken from literature (Rosso et al., 1996; Giménez and Dalgaard, 2004; Lakshmanan and Dalgaard, 2004), and 22 challenge tests in cold-process non-smoked salmon (Peterson, et al., 1993; Pelroy, et al., 1994; Niedziela, et al. 1998). Model 1: Augustin and Carlier (2000a). Model 2: Augustin and Carlier (2000b). Model 3: Ross (FAO/WHO, 2004), modified by Giménez and Dalgaard (2004). Model 4: Devlieghere et al (2001), modified by Giménez and Dalgaard (2004). Model 1': Augustin and Carlier (2000a), without phenolic effect $\left(P_{\max }=\infty\right)$. Model 2': Augustin and Carlier (2000b), without phenolic effect $\left(P_{\max }=\infty\right)$. Model 3': Ross (FAO/WHO, 2004). Model 4': Devlieghere et al (2001). Model 5: Pathogen Modeling program (USDA, 2001). Model 6: Growth Predictor (IFR, 2004). Model 7: FDA (2003).

\section{Figures}

Figure 1. Growth curves of $L$. monocytogenes on cold-smoked salmon $\left(\log \mathrm{cfu} / \mathrm{cm}^{2}\right)$, after surfacecontamination of batches $\mathrm{A}$ (figure $1 \mathrm{~A}$ ) to $\mathrm{E}$ (figure $1 \mathrm{E}$ ). Experimental results (grey squares: $4^{\circ} \mathrm{C}$, black squares: $8^{\circ} \mathrm{C}$ ) were fitted by least-squares regression with the selected primary model without lag (grey solid line: $4^{\circ} \mathrm{C}$, black solid line: $8^{\circ} \mathrm{C}$ ), and the Baranyi model (black dotted line) for one curve (batch $\mathrm{E}, 8^{\circ} \mathrm{C}$ ).

Figure 2. Growth curves of the mesophilic food flora in cold-smoked salmon (log cfu/g), batches $A$ (figure $2 \mathrm{~A}$ ) to $\mathrm{E}$ (figure $2 \mathrm{E}$ ). Experimental results (grey squares: $4^{\circ} \mathrm{C}$, black squares: $8^{\circ} \mathrm{C}$ ) below a limit of quantification are represented at this limit with a vertical bar. For two batches, $\mathrm{A}$ and $\mathrm{C}$, growth curves were fitted by least-squares regression with the selected primary model without lag (grey solid line: $4^{\circ} \mathrm{C}$, black solid line: $8^{\circ} \mathrm{C}$ ). 
Figure 1
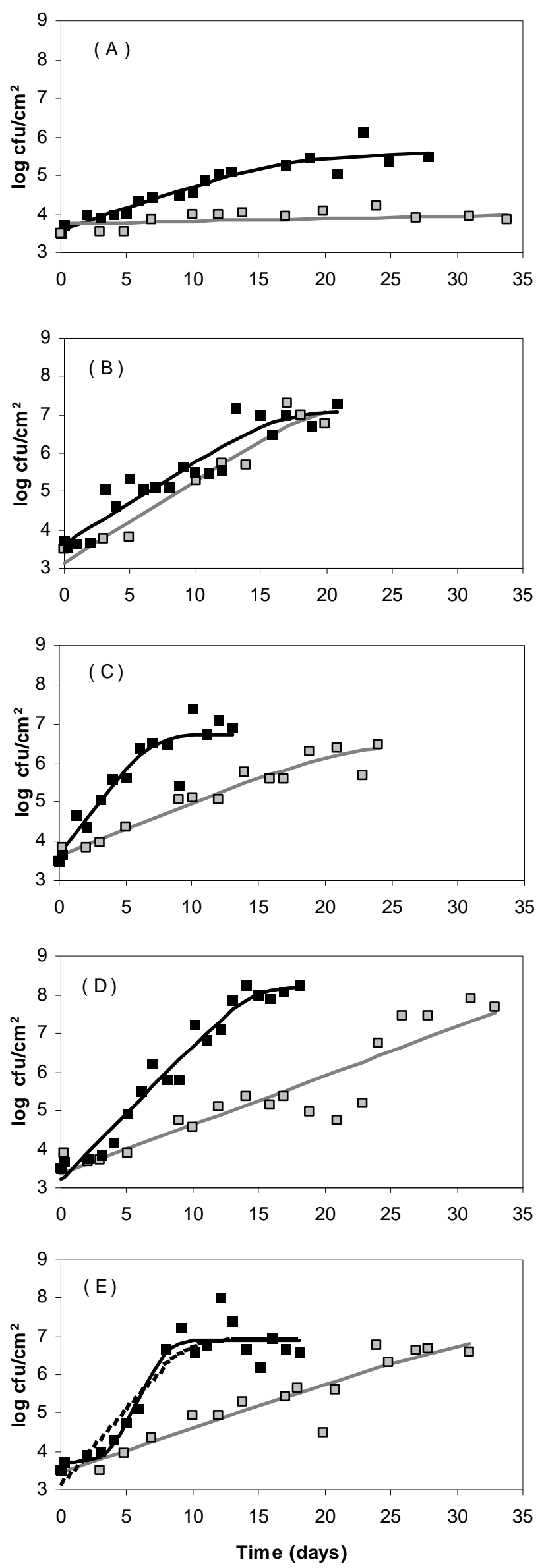
Figure 2
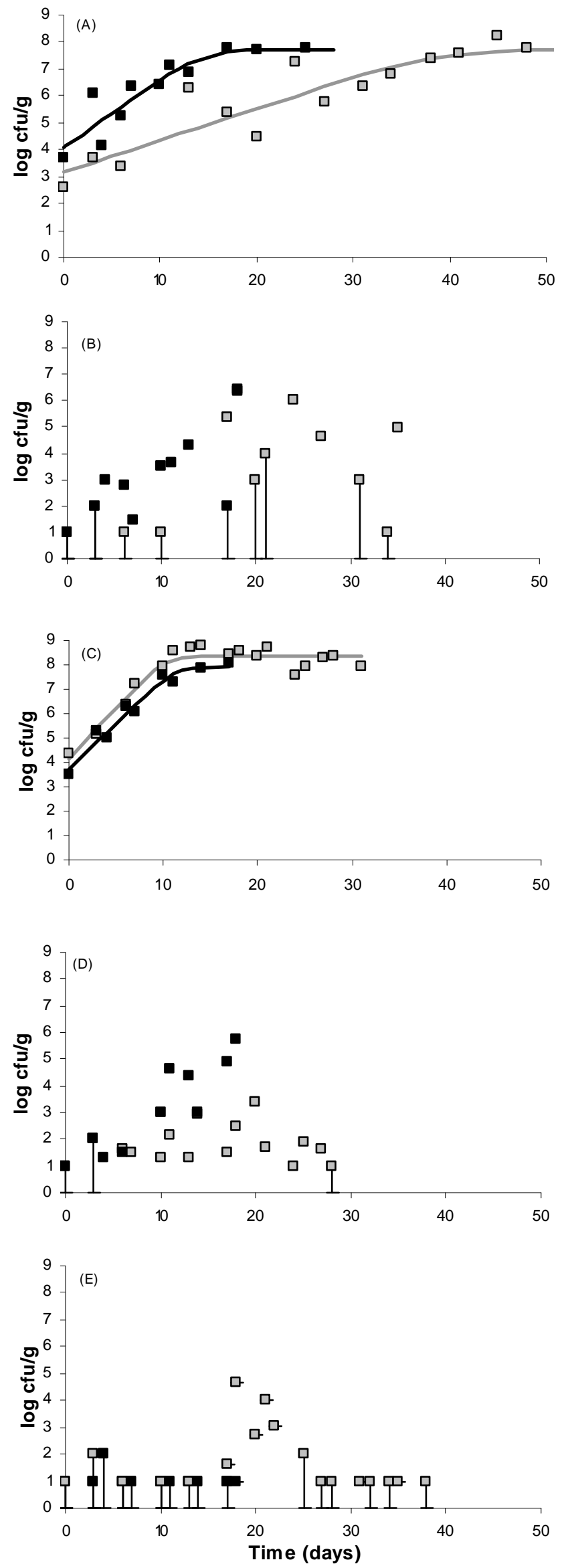